\title{
MONITORING OF SPACE DEBRIS ROTATION BASED ON PHOTOMETRY
}

\author{
N.Koshkin, L.Shakun, E.Korobeinikova, S.Melikyants, S.Strakhova, V.Dragomiretsky, A.Ryabov, \\ T.Golubovskaya, S.Terpan \\ Astronomical Observatory of Odessa I.I.Mechnikov University \\ Nikkoshkin(a)yahoo.com
}

\begin{abstract}
The number of spacecraft and space debris (SD) in orbit has become so great that there is a real threat to flight safety. The task of precision calculation of the upcoming positions of any space objects (SO) in orbit in order to predict dangerous mutual approaches and to solve practical tasks has become topical. For the development of a modern orbit propagation model and the associated unified forecast of the evolution of orientation and rotation of an uncontrolled satellite, it is necessary to rely on long-term series of high-quality measurements and their analysis. At present, the direction of research on determining the state of SO rotation around a center of mass has become more and more developed. In our work, we analyze the results of photometric observations of several large objects of space debris obtained at the Astronomical Observatory of Odessa University using the KT-50 telescope during the last six years or more. The results of the evolution of the rotation rate and orientation of the Topex/Poseidon, Envisat, Oicets, Cosmos-2487 (KondorE) and Sich-2 satellites are presented.
\end{abstract}

Keywords: Space debris; Photometry; Period of rotation; Orientation of rotation axis.

АБСТРАКТ. Кількість космічних апаратів (КА) і тіл космічного сміття (КС) на орбіті сьогодні стала настільки великою, що виникла реальна загроза безпеці польотів. Зробилась актуальною задача прецизійного розрахунку майбутніх положень будь-яких космічних об'єктів (КО) на орбіті з метою прогнозування небезпечних взаємних зближень та для вирішення інших практичних завдань. Для розвитку сучасної моделі орбітального поширення і пов'язаного з ним прогнозу еволюції орієнтації та обертання неконтрольованого супутника необхідно спиратися на тривалі ряди високоякісних вимірювань та їхній аналіз. На початковому етапі освоєння космосу головним завданням спостережень КА було вимірювання їхніх положень серед зірок з метою забезпечення прогнозу наступного циклу спостережень. Але коли кількість КА і тіл космічного брухту на орбіті зросла настільки, що виникла реальна загроза безпеці польотів, актуалізувалося завдання прецизійного розрахунку майбутніх положень будь-яких космічних об'єктів на орбіті 3 метою прогнозування небезпечних взаємних зближень. На нинішньому етапі боротьби із засміченням навколоземного космосу і появи реальної технологіч- ної можливості активного видалення КС з орбіти, зросла роль фотометричних і інших некоординатних вимірювань КО для вирішення завдання по визначенню параметрів власного обертання великих космічних тіл навколо центру маси. В даний час спостерігається помітне зростання числа досліджень, що націлені на визначення параметрів обертання КО. Це продемонструвала і остання 7-ма Європейська конференція з космічного брухту, що пройшла в квітні 2017 року. У даній роботі ми аналізуємо результати фотометричних спостережень декількох великих об'єктів космічного брухту, що були отримані в Астрономічній обсерватоpiï Одеського національного університету ім. I.I.Мечникова 3 використанням телескопа КТ-50 протягом останніх шести або більше років. Наведено результати по еволюції швидкості обертання і орієнтації KA Topex/Poseidon, Envisat, Oicets, Cosmos-2487 (Kondor-E) та Sich-2.

Ключові слова: Космічний брухт (сміття); Фотометрія; Період обертання; Орієнтація вісі обертання.

\section{Introduction}

As the number of tasks solved using spacecraft (SC) orbiting the Earth and the corresponding increase in the number of existing and planned space constellation, as well as the quality and quantity of observations of these bodies improves, the objectives of the space awareness has change. At the first stage of space exploration, the main task of spacecraft observation was to measure their position on the stars background to ensure the prediction of the subsequent observation cycle. When the number of spacecraft and space debris (SD) in orbit became so large that there was a real threat to flight safety, the task of precise calculation of the upcoming positions of any space objects (SO) in orbit was actualized in order to predict of dangerous mutual approaches. At the present stage of striving for clearing of near-Earth space and the emergence of a real technological possibility of active debris removal (ADR) out of orbit, the role of photometric and other non-coordinate measurements of SO has increased to solve the problem of determining the parameters of proper spin of large bodies in orbit. This data should be used both when planning ADR missions and to provide highly accurate prediction of the movement and SO's approaches, since the upper atmosphere drag significantly depends on the crosssectional area, i.e. on body orientation. 
Currently, there is a noticeable increase in the number of researches aimed at determining the parameters of the SO's spin. This was demonstrated by the last 7th European Conference on Space Debris, held in April 2017. Many reports were devoted to determining the orientation and monitoring the spacecraft rotation about center of mass, developing the optical observational networks, analyzing the situation in low-Earth orbits (LEO), of methods for reducing the risk of space flight and discuss of the ADR relevance. According to L.Anselmo and C.Pardini (Anselmo, 2017, see Fig. 1), for average solar activity level, for a spacecraft having the mass to area ratio equal $85 \mathrm{~kg} / \mathrm{m}^{2}$ and circular orbit with initial height of $\sim 740 \mathrm{~km}$, his lifetime is 100 years, and for another with initial height of $985 \mathrm{~km}$ - about 1000 years.

Boer (2017) describes the international network TAROT, operating since 1999 under the authority of CNES. The network consists of 4 high-speed robotic optical telescopes, three of which are located in the southern hemisphere. The largest of them (Zadko $1 \mathrm{~m}$ telescope) is located in Australia at the Gingin observatory and has a sensitivity of up to $20^{\mathrm{m}}$ in the R-band. Fiedler (2017) and colleagues described the first results of the SMARTnet network. This network, which is German-Swiss at the first stage, declares openness to membership with a free exchange of primary measurement results. The network consists of two $20 \mathrm{~cm}$ and one $50 \mathrm{~cm}$ automated optical telescopes located in Europe. It is planned to expand the network points in Australia and South America. The Spanish Space Surveilance and Tracking System (S3T) is described in the report of Gómez (2017). The system consists of a national operating center and a set of groundbased sensors, which include five optical telescopes (including one active), as well one radar. The system began work in mid-2016, but the autonomous catalogue has already been created, based on observations from a network of sensors. In the Flohrer (2017) report outlined the ESA concept of development of SSA as consisting of three areas, including space surveilance and tracking (SST). At the same time, at this stage (2017-2020), the main initiative is given to the national SST resources.

In the work of Alives (2017) the automatic assessment of the orientation and rotation of the spacecraft based on ISAR-images (using the example of Envisat observations) by building chains of consecutive fitted images of model is considered. The work of Sommer (2017) and other German researchers is also devoted to the spin of Envisat. Based on the set of 19 ISAR-images, they clarify the kind of the change in the inertial spin rate of the satellite over time, covering the period from August 2011 to March 2017. Silha (2017) analyzes the rotational motion and orientation of SD using simulations of various observation methods, including passive photometric measurements, SLR and radar images. In this paper, the ESA project "Debris Attitude Motion Measurements and Modeling" aimed at short-term (days) and long-term (months and years) prediction of the rotation of large SD objects as part of the ADR task is considered. Kirchner (2017) with colleagues who had previously developed a method for determining the attitude of satellites equipped with a laser reflectors unit based on range (distance) measurements by a high-frequency laser, in the new work complement laser data too measurements of target brightness using a highly sensitive photometer. The targets used are Envisat, Oicets, as well as many inactive Glonass satellites. In particular, variations in the rotation period of the Glonass-41 over almost 3 years are noted.

In the work of Šilha, Schildknecht (2017) the Data Base of light curves of almost 500 SOs obtained in AIUB for 10 years using the 1-m ZIMLAT telescope is presented. Rotational rates were estimated for 397 objects and the classification of light curves by their complexity was proposed, which are reflecting the state of body rotation. The orientation and rotation of the SWISSCUBE CUBESAT small satellite is described in Pittet (2017). To obtain the data, satellite lightcurves are used, as well as satellite radio reception data and gyroscopes measurements on board. Benson (2017) with colleagues analyzed the GSS light curves of GOES series. The data were obtained at the Lowell Observatory in Flagstaff in 2016 using $1.8 \mathrm{~m}$ and $1.1 \mathrm{~m}$ optical telescopes. They try to explain the complex and non-periodic kind of the light curve by the presence of two fundamental periods for tumbling motion of satellite. One period corresponds to spin around either of the satellite's extremal axes and the second period to precession and nutation of that axis about the rotational angular momentum vector.

\section{Equipment and method of observation}

The KT-50 high-speed telescope (Shakun, 2016) is equipped with a GPS-receiver for accurate time measurements and digital angle encoders on the telescope's axes. Location of telescope - longitude 30.755667, latitude 46.477778, height $56 \mathrm{~m}$. Alt-azimuth mount, $\mathrm{D} / \mathrm{F}=$ 500/2000; the receiver TV-CCD WAT 902H2 Sup, frame size of $768 \times 576$ pixels, FOV is $12 \times 9$ arcmin, resolution scale about $1 \mathrm{asec} / \mathrm{px}$ (Shakun, 2014).

The mount allows track of LEO satellites in the altitude range of $350 \div 5000 \mathrm{~km}$, in orbits with an inclination i> $45^{\circ}$; the maximum tracking rate is $\sim 4 \mathrm{deg} / \mathrm{sec}$; the mean standard deviation of the astrometric measurements is $\sim 1$ asec (Shakun, 2014). The photometry is currently carried out without light filters (in integral light) with the time resolution of $\Delta \mathrm{T}=0.02 \mathrm{~s}$; the limiting stellar magnitude value for TV-CCD mode on frequency equal of $25 \mathrm{fps}$ is 9-10m. Requires re-equipment of executive engines to automate tracking at high speeds.

\section{Topex and Envisat spacecrafts rotation monitoring}

The photometric monitoring of space debris for several years allows detecting unexpected trends in the change of their rotation parameters. The analysis of the light curves makes it possible, first of all, to notice a change in the visible period of rotation of the body. In Figure 1 shows the change in the synodic (that is, not inertial, visible) rotation period of the Topex/Poseidon satellite (due to technical problem was decommissioned at the end of 2005), obtained from our measurements during June 2009 - June 2018. During this time span, the rotation period of the satellite decreased from 18.9 seconds to 10.3 seconds. This satellite orbits with an inclination of $66^{\circ}$, remaining at an altitude of about $1340 \mathrm{~km}$ above the Earth's surface, 


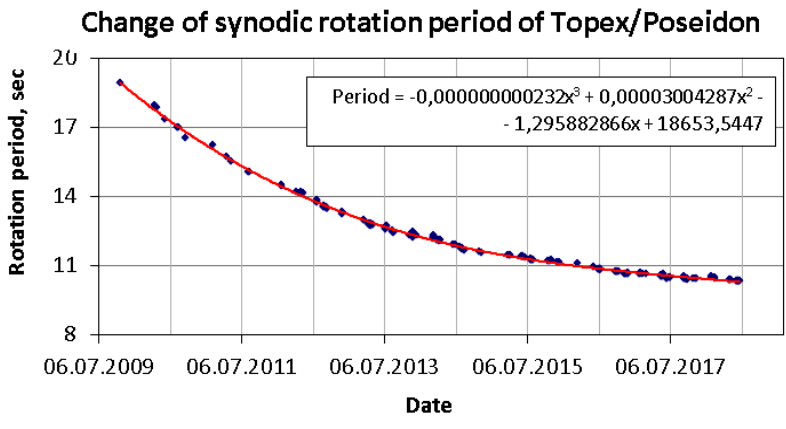

Figure 1: The change in the visible rotation period of the Topex/Poseidon satellite, obtained from photometric measurements using the KT-50 telescope during 20092018. In this cubic fit, the argument is counted from 0101-2014 in days.

has an asymmetric shape because of one large solar panel. As shown in Kucharski (2017) in this case, the pressure of direct solar radiation leads to acceleration of satellite rotation. At present, the rate of spin period change has slowed, but has not yet fallen to zero, that is, Topex continues to slowly accelerate its rotation, reducing time of full revolution as about a quarter of second per year, or $2.6 \%$. Note that the rate of the decrease in the visible period is fluctuating on different time scales. In particular, two fluctuations are clearly observed during half a year.

Another important characteristic of satellite rotation in orbit is the orientation of the vector of the spin axis in space (we assume that it coincides with the vector of angular momentum) and its movement with time. In the work of Kucharsky (2017) the orientation of the spin axis at 401 positions during time was determined on the basis of data from Satellite Laser Ranging (SLR) of Topex over two years (June 2014 - June 2016). In Figure 2 shows the movement of the pole of rotation of Topex in the equatorial (left) and orbital (right) coordinate system, which is calculated according to the theory given in this work. We see that an oscillatory motion of the spin axis occurs near the orbital plane with an amplitude of about 12 degrees around a point close to the perigee of the Topex orbit.

In order to test this solution for the orientation of the spin axis of Topex, we consider the light curves of this satellite, obtained at the same time in Odessa using KT50 telescope. Figure 3 shows a fragment of the observed light curve of June 23, 2014 (below) and the corresponding fragment of the theoretical light curve of the opticalgeometric model of Topex (above) calculated for the same conditions of lighting and observation and for the above indicated orientation of its spin axis in space. It is necessary to state a good qualitative correspondence between the theoretical and the observed light curves during the five rotation cycles shown. This can be regarded as an independent confirmation of the spin axis solution obtained on the basis of SLR data only.

The synchronous basic (baseline) photometric measurements of the Topex during a short time interval were obtained on July 28, 2014 in Odessa and in Kazan, MMT (see Fig. 4). The pattern of satellite brightness variation is
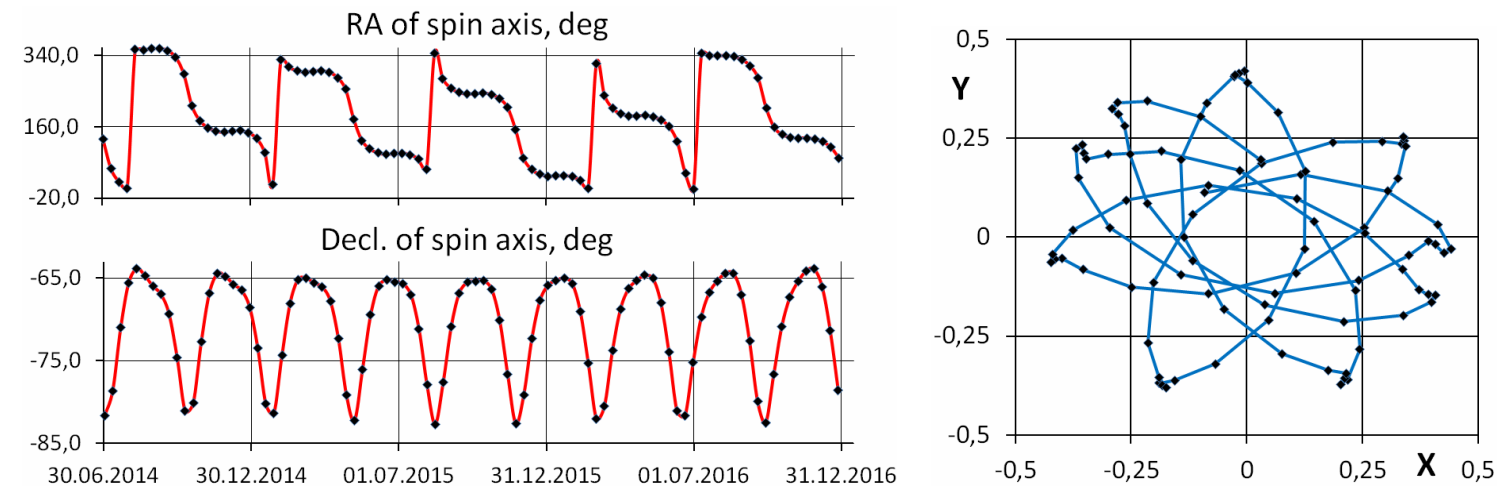

Figure 2: The Topex/Poseidon orientations of spin axes in equatorial coordinate system (left). The projection of the Topex spin axes on the XY-plane, which is perpendicular to the orbit perigee direction (right).

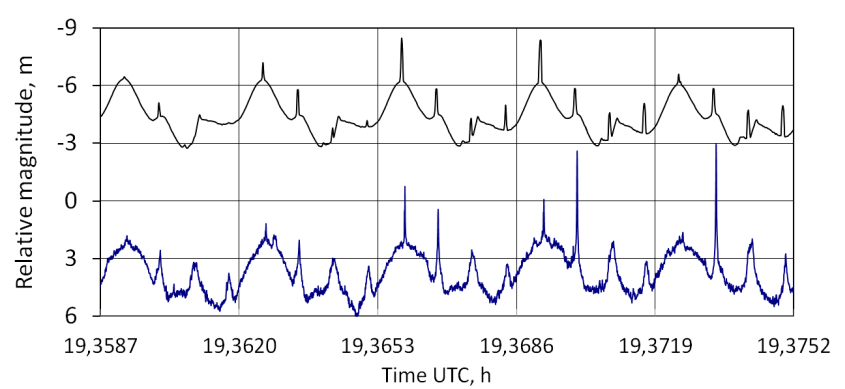

Figure 3: Fragment of the observed light curve dated June 23, 2014 (below) and the theoretical light curve of the Topex model (above) calculated for its rotation axis orientation in space RA_rot $=174^{\circ}$, Decl_rot $=-77^{\circ}$.

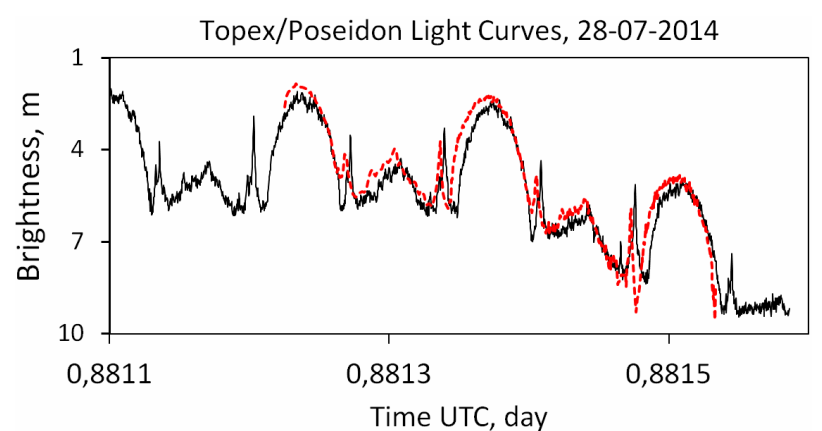

Figure 4: Fragment of the Topex/Poseidon light curve dated July 28, 2014, observed simultaneously from two points. The solid black curve - Odessa, KT-50; red dotted curve - Kazan, MMT (Katkova, 2017; http://astroguard.ru/satellites). 


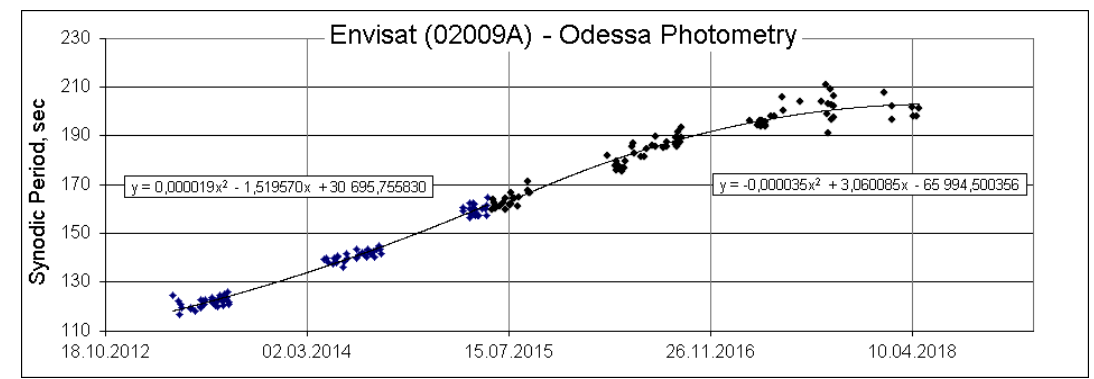

Figure 5: Change in the visible period of Envisat rotation, obtained from the observed light curves, Odessa, KT-50. From April 2013 to May 2015, the rotation period increased with acceleration (Koshkin, 2016); from May 2015 to April 2018 - it is increased with a slowdown.

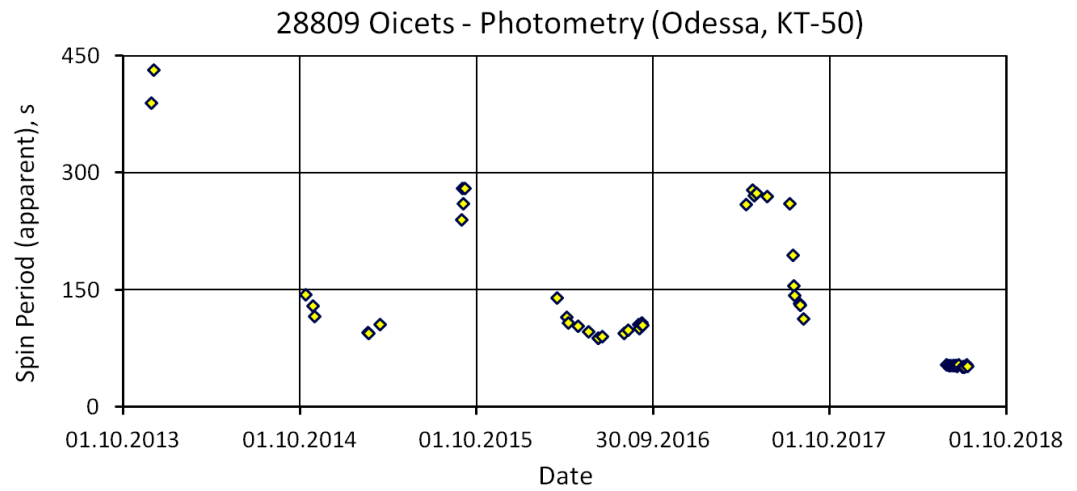

Figure 6: The change of the apparent rotation period of the Oicets satellite, obtained from the observed light curves, Odessa, KT-50.

almost completely repeated on both light curves, but with a small but significative time shift, which is probably explained by the parallactic delay for spaced observation stations and depends on the direction and rotation speed of the satellite.

In paper Koshkin (2016) on the basis of photometry in 2013-2015, we estimated the rate of rotation period change of another large space debris object - the inactive European satellite Envisat orbiting on altitude of $760 \mathrm{~km}$ with inclination of $98^{\circ}$. This object also has a very asymmetrical shape, but unlike the case described above, the Envisat's rotation period increases with time, that is, the satellite's rotation slows down. While (at the same time), according to measurements of the visible period of 20132015 , as well as according to estimates of the inertial period, it was possible to conclude that the rotation period does not grow linearly, but with a slight "acceleration" (weak quadratic dependence on time). Pittet (2018) and colleagues during a similar interval of measurements using the technology of satellite laser range (SLR) estimate the slowdown of the rotation period of Envisat. They have developed a method for determining the rotational motion of a satellite (the period and orientation of the rotation axis) during a single pass.

In the more late work of Sommer (2017) based on their own data on the Envisat rotation period, obtained using a inverse synthetic aperture radar (ISAR) during the period 2013-2017, and analyzing our and other available data of colleagues, they clarify the nature of the inertial period change of the satellite evaluating it as linear. A theoretical analysis of Envisat's long-term rotational motion and a comparison with estimates of its orientation and rotation period from observational data is given in Sagnières, 2018. A distinct nutation of the satellite angular momentum vector relative to the orbit normal is predicted, and its period evaluated of the order of several days. Over time, it is expected that the nutation of the rotation axis will become more and faster simultaneously with a decrease of the angular velocity. Our new photometric measurements from June 2015 to April 2018 showed that in 2015 the nature of Envisat deceleration changed and in the last two years the growth of the rotation period almost stopped (Fig. 5). We also note that the scatter of the values of the visible period in 2017-2018 has increased markedly, which may indicate an increase in the nutation amplitude of the rotation axis in accordance with the Sagnières (2018) forecast.

\section{Different rotational behavior of LEO inactive spacecraft}

Other large objects of space debris demonstrate the complex nature of the change in rotational speed. In Figure 6 shows the change in the apparent spin period of the Oicets satellite, obtained according to photometry data on the KT-50 telescope from the end of 2013 to the middle of 2018. This spacecraft is in an almost circular orbit with altitude of about $570 \mathrm{~km}$ and inclination of $98^{\circ}$, and has been inactive since September 2009. As you can see, several intervals of acceleration and deceleration of the satellite rotation were observed. The cyclicity was about 600 640 days. 
The photometric observations during almost 1000 days of the Russian spacecraft COSMOS-2487 (Kondor-E) show an almost linear increase in the visible rotation period against time (Fig. 7). This spacecraft is in orbit with altitude of only $450 \mathrm{~km}$ and inclination of $74.7^{\circ}$ and carries a large SAR antenna measuring $6 \times 7$ square meters. Slow deceleration of rotation indicates the passive status of this spacecraft, although we do not know the official confirmation of this fact.

The communication with the Ukrainian remote sensing satellite Sich-2 was discontinued on December 12, 2012 due to battery failure. It remains in orbit at altitude of 690 $\mathrm{km}$ and inclination of $98^{\circ}$. Photometric monitoring of this inactive satellite is conducted by us from April 2013 to July 2018. Figure 8 presents data on the change of the photometric visible rotation period of this spacecraft obtained in Odessa and in Evpatoria (Ukrainian SSA Center). A few months after the failure, at the beginning of April 2013, the satellite rotated with frequency of 4.4 revolutions per minute (apparent rotation period was 13.6 seconds), but over time the rotation speed grew rapidly. By the middle of August 2013, Sich-2 was rotating with frequency of 9.2 revolutions per minute $\left(P_{-}\right.$app $\left.=6.52 \mathrm{~s}\right)$.
After that, there was a long period of slow growth of the rotational speed and in July 2018 the apparent period is 3.64 seconds.

This spacecraft has a symmetrical cube shape and four solar panels parallel to one face. Therefore, it can be assumed that the rotation axis in the satellite body coincides with the longitudinal axis of symmetry or with one of the normals to the side faces (Lopachenko, 2013). The light curve of this spacecraft usually shows a weak-specular reflection of light by the satellite planes. Figure 9 shows the Sich-2 light curve obtained on May 11, 2018 in Odessa. At beginning of the passage, acute but wide maxima of brightness are observed (see Figure10, the top composite curve is obtained by folde the first 10 cycles), at the end of the passage the phase angle has increased to $120^{\circ}$ and the maxima changed to rounded quasi-sinusoidal shape (Fig.10, the lower composite curve is obtained by folde the last 10 cycles of brightness fluctuations).

But in both areas we see that two diametrically opposite faces give a brighter shine and show the amplitude of the oscillation of about $4 \div 5$ stellar magnitudes, while the intermediate ones are 2-4 times smaller than the amplitude. This can be explained if it is assumed that brighter

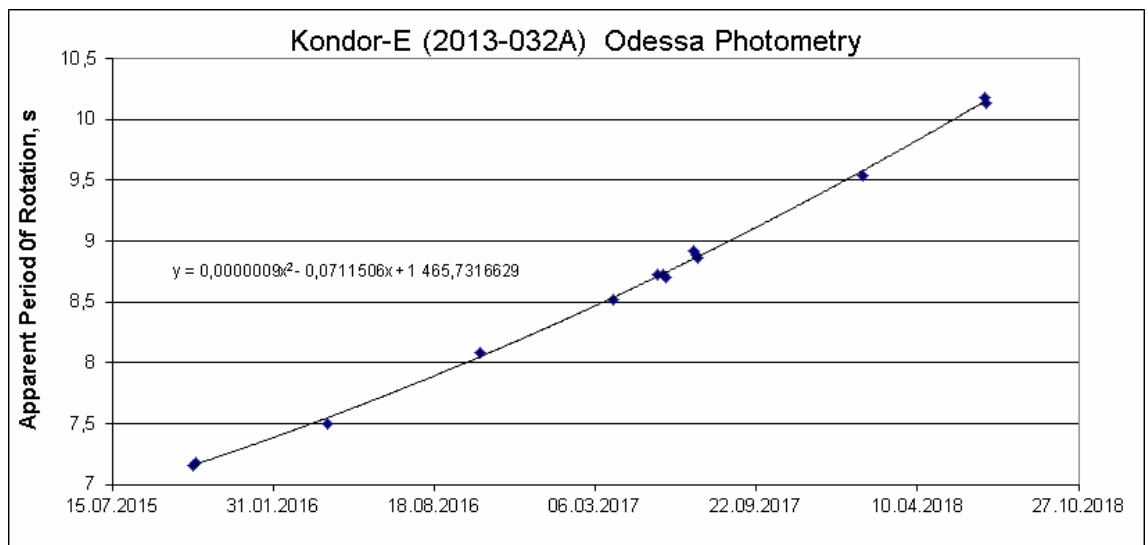

Figure 7: Change of the apparent rotation period of the COSMOS-2487 (Kondor-E) satellite, obtained from the observed light curves, Odessa, KT-50.

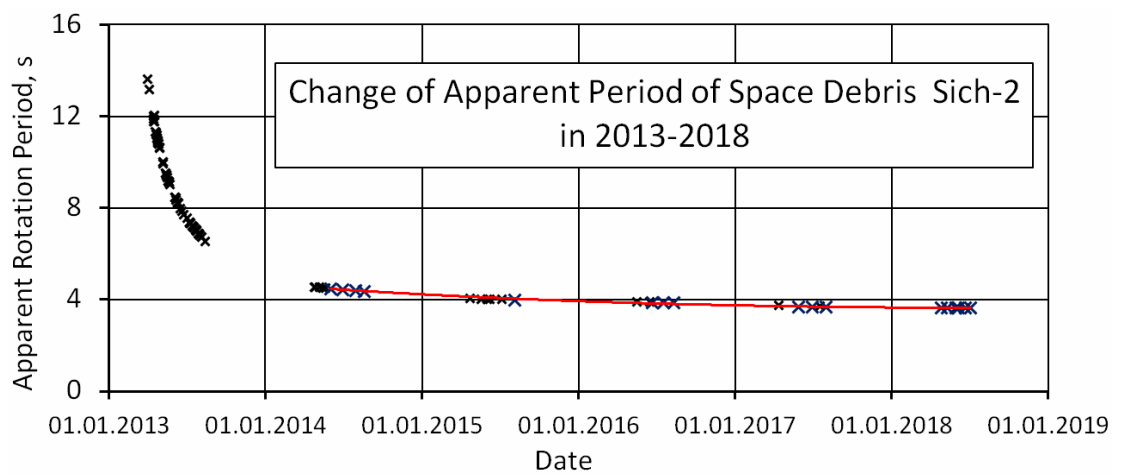

Figure 8: The change of the apparent rotation period of the Sich-2 satellite obtained from the observed light curves in Odessa on the KT-50 telescope and in Evpatoria, KOS "Sazhen" (AZT-28). 
Light Curve of Sich-2, Odessa, KT-50, 11.05.2018

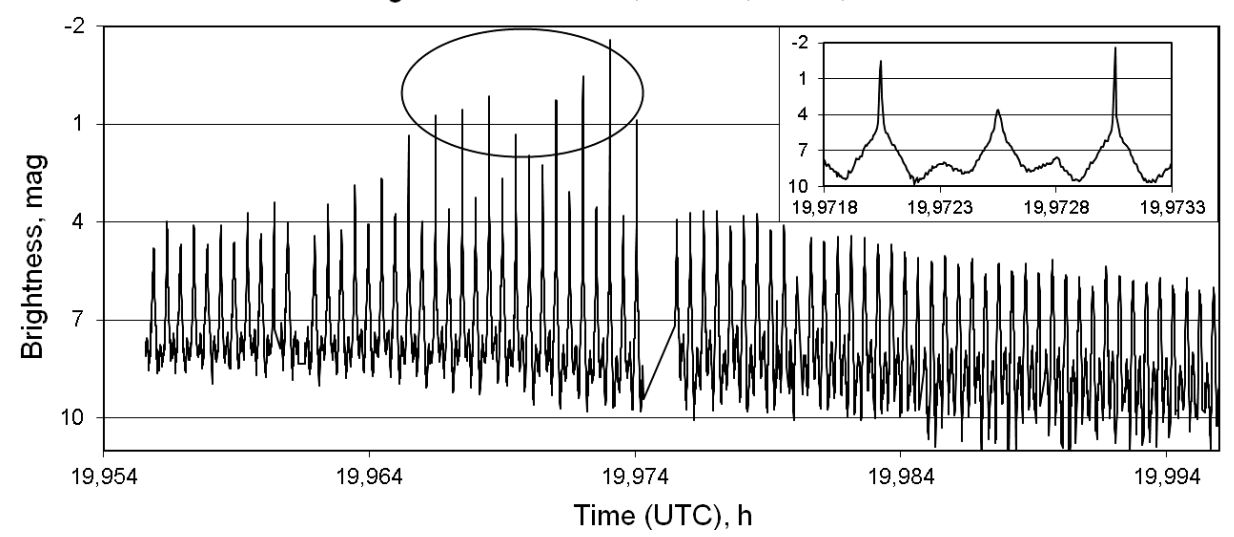

Figure 9: The light curve of the Sich-2 satellite dated May 11, 2018, obtained in Odessa using the KT-50 telescope. The oval marked the time interval when the specular reflection of light are observed. A fragment of the same light curve on a large scale is shown in the inset to demonstrate the mirror nature of the reflection of light during flashes.

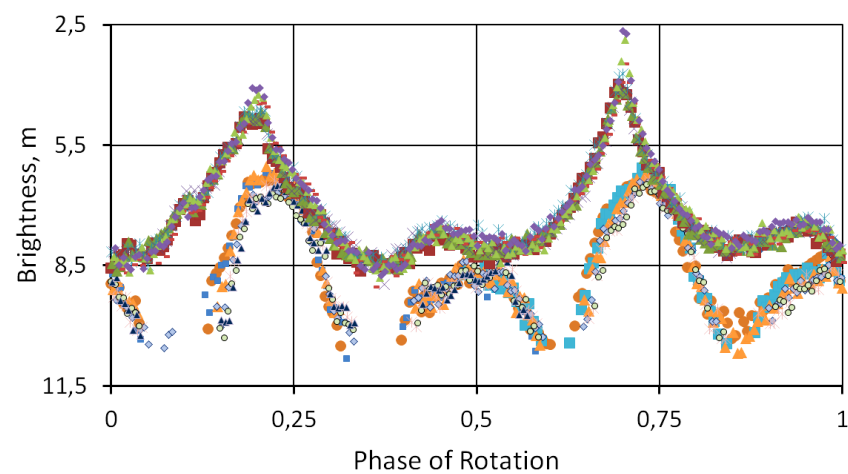

Figure 10: The convolution of the Sich-2 light curve dated May 11, 2018 with a period of 3.633 seconds. Two fragments of the folded light curve are shown. The upper composite curve includes the first 10 cycles of Sich-2 rotation; the lower composite curve includes the last 10 cycles.

flashes of shine are formed with the participation of flat solar panels. In this case, the rotation axis in the satellite body is parallel to the plane of these panels (or makes a small angle, that is, not strictly perpendicular to one of the side faces). This kind of Sich-2 light curves have in most passages, when the maximum satellite brightness does not exceed about $4 \mathrm{~m}$. But in rare passages (approximately in a quarter of cases), bright specular flashes appear on the light curve, during which the brightness increases by 3-5 mag (to $1 \mathrm{~m}$ and even to $-1 \div-2 \mathrm{~m}$ ). The like area is indicated on the light curve of May 11, 2018 (Figure 9) and on the insert we can clearly see the mirror nature of the flashes in this area of light curve. For such time intervals with bright specular flashes, we calculated the direction of the phase-angle bisectors $(\mathrm{PAB})$. All of them fall into a limited area in space: RA bis $=-3 \div 89^{\circ}$, Decl bis $=-41 \div+15^{\circ}$ (with a midpoint of RA_bis $=56^{\circ}$, Decl_bis $=-14.3^{\circ}$ ).

Taking into account the symmetry of the satellite shape and the fact that the angles between the actual normal to the orbit and the corresponding $\mathrm{PAB}$ remains on average close to $100^{\circ}$, it can be assumed that the rotation axis makes an angle close to $90^{\circ}$ with the normal of the 'reflecting' planes. Then the vector of the Sich-2 rotation axis over the entire time interval considered may experience oscillations near the mean pole RA_rot $=56^{\circ}$, Del_rot $=75.7^{\circ}$ (Fig.11).

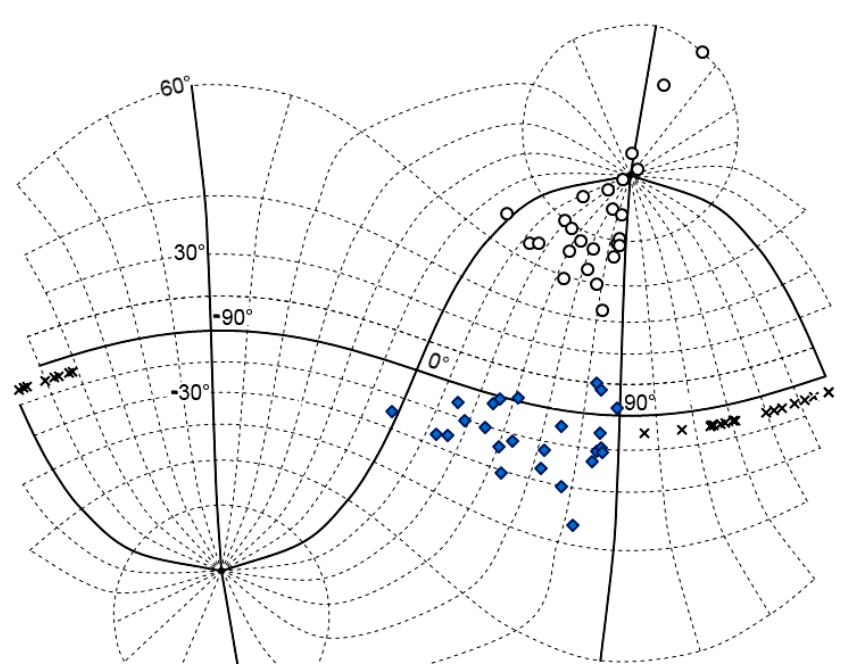

Figure 11: The location of PAB directions on the celestial sphere (shown by diamondes. Calculated for the middle of intervals when are appear bright specular flashes of brightness) for 25 light curves of the Sich-2 obtained from 16-05-2013 through 01-08-2018. Open circles indicate the estimated corresponding positions of the spacecraft rotation axis for these passages. The crosses indicate the directions of the normals to the plane of the satellite orbit during of these observations.

Figure 12 shows a fragment of the same light curve of the Sich-2 spacecraft obtained on May 11, 2018 (the lower curve) and the theoretical light curve of the satellite's optical-geometric model (upper curve) is given for comparison. The theoretical curve was obtained under the same lighting and observation conditions as the real one, and the rotation axis in the model body is perpendicular to one of the side faces of the cube (parallel to the solar panel plane), and in the inertial equatorial coordinate system it is directed to the pole RA_rot $=56^{\circ}$, Decl_rot $=75.7^{\circ}$. Despite the imperfection of the parameters characterizing the light scattering by this model, nevertheless, for the indicated orientation of the rotation axis in space, a similar pattern of changes in the brightness of the real Sich-2 satellite and its model was obtained. In order to independ 

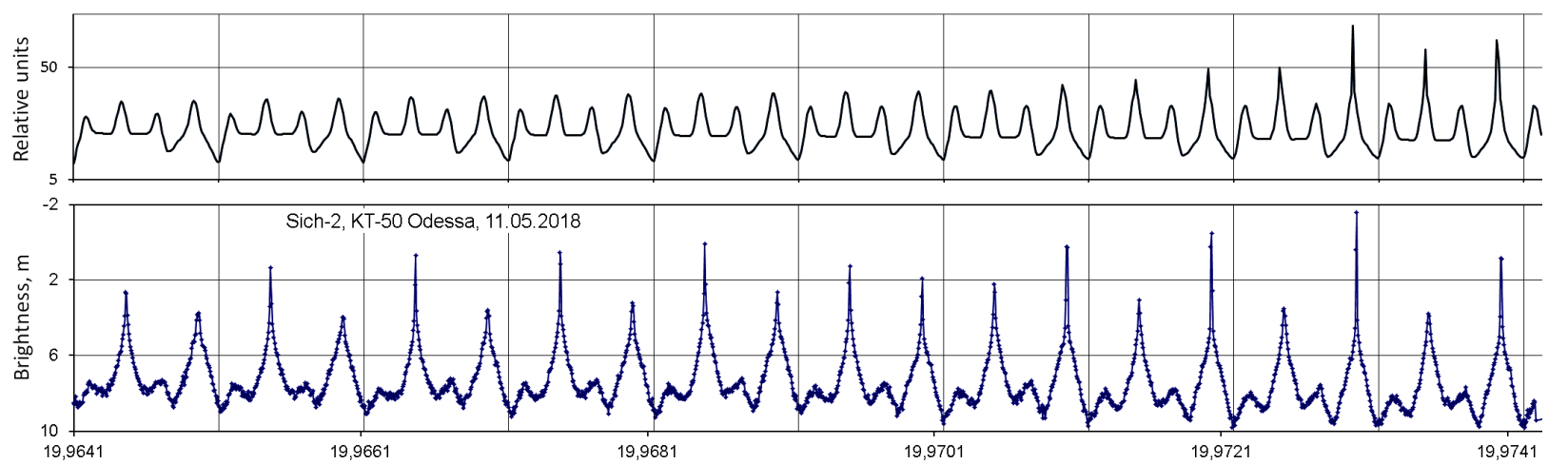

Figure 12: The fragment of the light curve of the Sich-2 spacecraft dated May 11, 2018, obtained in Odessa using the KT-50 telescope (below) and the theoretical light curve of the satellite model (above) calculated for the same conditions and orientation of its rotation axis in the equatorial system: RA_rot $=56^{\circ}$, Decl_rot $=75.7^{\circ}$.

ently confirm the results of our analysis, it is advisable to obtain synchronous basis photometric observations of the Sich-2 satellite with a high measurement frequency and impeccable timing.

\section{Conclusion}

The development of a modern orbital propagation model and a closely related unified forecast of the evolution of attitude and rotation of an uncontrolled satellite should be based on long-term series of high-quality measurements and their analysis. In our work, we analyze the results of photometric observations of several large objects of space debris obtained at the Astronomical Observatory of Odessa University using the KT-50 telescope over the past six years. Different conditions and factors of near-Earth space influence the rotation of these spacecraft around the center of mass in different ways. First of all, we can estimate the rotation speed of the satellites and its change over time. Some inactive satellites demonstrate a slowing down of rotation under the action of moments of gravitational forces, a magnetic field, and the pressure of sunlight and a rarefied upper atmosphere, while others, on the contrary, experience an acceleration of rotation at a certain time interval. Still others show the cyclical nature of these processes.

The analysis of the geometric conditions in which the brightness of a satellite is measured (especially the presence of specular reflection of light by its surface) makes it possible in some cases to estimate the orientation of its axis of rotation in the inertial and orbital coordinate system. As a rule, at the first stage, this is the rough average position of the rotation axis in the body and in space; however, this allows you to continue the analysis of the available photometric data by simulating and comparing the real and theoretical light curves of the satellite. This implies the importance of the adequacy of such optical-geometrical models to real prototypes in orbit. A preflight measurement of the main optical parameters and characteristics of the spacecraft is strongly required. It is also obvious that it is necessary to include in the model analysis the complex nature of the satellite rotation, including nutational motion with variable amplitude, which will make full use of the high information potential contained in high-frequency measurements of the brightness of artificial bodies in orbit.

\section{References}

Anselmo L. and Pardini C.: 2017, in Proc. of 7th Europ. Conf. on Space Debris, Sect. P-Modeling (17-21 Apr., Darmstadt, Germany) https://conference.sdo.esoc.esa.int/.

Avilés M., et al.: 2017, in Proc. of 7th Europ. Conf. on Space Debris, Sect. MEAS-3 (17-21 Apr., Darmstadt, Germany).

Benson C., et al.: 2017, in Proc. of 7th Europ. Conf. on Space Debris, Sect. P-OBS (17-21 Apr., Darmstadt, Germany).

Boër M., et al.: 2017, in Proc. of 7th Europ. Conf. on Space Debris, Sect. SST-1 (17-21 Apr., Darmstadt, Germany).

Fiedler H., et al.: 2017, in Proc. of 7th Europ. Conf. on Space Debris, Sect. SST-1 (17-21 Apr., Darmstadt, Germany).

Flohrer T., Krag H.: 2017, in Proc. of 7th Europ. Conf. on Space Debris, SST-1 (17-21 Apr., Darmstadt, Germany).

Gómez I. A., et al.: 2017, in Proc. of 7th Europ. Conf. on Space Debris, SST-1 (17-21 Apr., Darmstadt, Germany).

Katkova E., et al.: 2017, "Photometry of the satellite at MMT-9 for three years", (http://astroguard.ru/data/ data_open/2017/articles/articles_2017_1.pdf, http://astroguard.ru/satellites)

Kirchner G., et al.: 2017, in Proc. of 7th Europ. Conf. on Space Debris, MEAS-3 (17-21 Apr., Darmstadt, Germany).

Koshkin N., et al.: 2016, Adv. in Space Res., 58, 358. (https://doi.org/10.1016/j.asr.2016.04.024)

Kucharski D., et al.: 2017, Earth and Space Science, 4, 661. (https://doi.org/10.1002/2017EA000329)

Lopachenko V., et al.: 2013, Bull. of Ukrainian EOP Laboratory, $8, \quad 79$. (http://cdsads.u-strasbg.fr/abs/ 2013BUEOP...8...79L)

Pittet J.-N., et al.: 2017, in Proc. of 7th Europ. Conf. on Space Debris, MEAS-3 (17-21 Apr., Darmstadt, Germany).

Pittet J.-N., Silha J. and Schildknecht T.: 2018, Adv. in Space Res., 61, 1121. (doi:10.1016/j.asr.2017.11.035)

Sagnières L. and Sharf I.: 2018, J. of Guidance, Control and Dyn., 1-13. In print. (https://doi.org/10.2514/ 1.G003647)

Shakun L.S., Koshkin N.I.: 2014, Adv. Space Res., 53 (12), 1834.

Shakun L., et al.: 2016, Odessa Astron. Publ., 29, 217. (http://oap.onu.edu.ua/article/view/85234)

Silha J., et al.: 2017, in Proc. of 7th Europ. Conf. on Space Debris, Sect. MEAS-3 (17-21 Apr., Darmstadt, Germany).

Silha J., Schildknecht T., et al.: 2017, in Proc. of 7th Europ. Conf. on Space Debris, Sect. MEAS-1 (17-21 Apr., Darmstadt, Germany).

Sommer S., et al.: 2017, in Proc. of 7th Europ. Conf. on Space Debris, MEAS-3 (17-21 Apr., Darmstadt, Germany). 